\title{
Balthasar Hubmaier and His Eighteen Articles
}

\author{
Danijel Časni \\ Biblijski institut, Zagreb \\ dcasni@bizg.hr
}

UDK:276:27-722

Review paper

https://doi.org/10.32862/k.12.1.3

\begin{abstract}
The paper talks about the renowned Anabaptist reformer, Balthasar Hubmaier, whose works were a significant contribution to the development of the early Anabaptist movement. In 2018 we mark the 490 th anniversary of his death of being burned at the stake for his religious beliefs. In the paper, we see an outline of Hubmaier's biography and an overview of his creative work. Special attention is given to his first work from June 1524, which contains 18 articles, and is called, "Achtzehn schluß rede so betreffende ein gantz Cristlich leben." The articles show Hubmaier's view on theology, ecclesiology, and pastorology at the beginning of his reformation work.
\end{abstract}

Key words: Balthasar Hubmaier, Anabaptists, articles, Ulrich Zwingli, Reformation

\section{Introduction}

Along with John Calvin, Martin Luther, and Ulrich Zwingli, Balthasar Hubmaier was one of the leading reformers of the $16^{\text {th }}$ century. He was reminded of the Biblical foundation of the Anabaptist doctrine of baptizing believers, ie., baptizing those who believe based on their profession of faith. He rejected infant baptism, which was a precedent in $16^{\text {th }}$ century Christianity. Hubmaier actively advocated the separation of Church and state, and he rejected the practice of the state Church which was present in the Roman Catholic and Protestant Christian worlds of the day. His first work from 1524 is entitled, "Achtzehn schlu $\beta$ rede so betreffende 
ein gantz Cristlich leben" (Eighteen theses regarding the whole of Christian life). The reason for this update on Hubmaier's work is marking the $490^{\text {th }}$ anniversary of his death.

\section{Hubmaier's Biography and His Works}

Balthasar Hubmaier was born in Freidburg, Germany, near the city of Augsburg. The year of his birth has not been determined with certainty, so it is assumed he was born between 1480 and 1485 (Bergsten 1978, 48). In an article named, He Died for the Freedom of Faith, J. Nordenhaugh $(1969,65)$ cites 1483 as the year of Hubmaier's birth.

There is very little data about Hubmaier's childhood. He came from a farming family. He got his education in the Augsburg Latin school for boys (Vedder $1905,26)$. Upon receiving his elementary education, on May $1^{\text {st }}, 1503$ he began studying theology at the Freidburg University in Breisgau. The University was founded in 1457 and is one of the oldest universities in Germany. While studying there, Hubmaier ran out of finances, which is why he was forced to drop out. He then got a job at a school in the Swiss town of Schaffhausen. Later, he continued with his studies and earned a Bachelor's degree in Divinity in 1510. At the same time, he was ordained as a priest (Nordenhaugh 1969, 65). Most probably in 1511, he earned a Master's Degree (Vedder 1905, 27).

Hubmaier's mentor at the university was called Johann Eck. Although Hubmaier was one of the older students, that didn't stop him from becoming one of the best as well. At the graduation ceremony, Eck praised Hubmaier with these words, "It's wonderful to remember the comprehensiveness and seriousness with which he mastered the philosophical sciences; how he listened to his teachers attentively and how he took notes tirelessly during the lectures; a diligent reader, a tireless listener, and a zealous helper to other students." (Estep 1986, 47). Johann Eck went on to become a fierce opponent of Martin Luther's Reformational stances. In the autumn of 1510, Johann Eck left the Freidburg University and joined the University of Ingolstadt. Hubmaier followed the path set by his mentor. In February 1512, Hubmaier also arrived at the University of Ingolstadt in order to continue pursuing his studies. In September of the same year, he finished his Ph.D. and became a professor of Divinity at the University of Ingolstadt. He was a skilled preacher and a priest at the largest church in the city (Bergsten 1978, 50). He was reputable and he became deputy rector at the University. He held the position until 1515.

The next year, in 1516, he left Ingolstadt and went on to become a priest in the cathedral in the city of Regensburg. In Regensburg, Hubmaier built a chapel to the "Mary Most Holy" on the foundations of a former synagogue, and it beca- 
me a place of pilgrimage (Estep 1986, 49). Regardless of his well-being caused by the alms of the pilgrims and by the popularity he gained as an excellent preacher, Hubmaier found no pleasure in all this. That is why he decided to go elsewhere.

In 1521, he began serving as the parishioner of the church in Waldshut on the Rhine, situated near the Swiss border. The times in which Hubmaier lived were turbulent because the spark of the Reformation had already been lit all across Germany. Waldshut was under Austrian rule, but due to the fact that it was so close to the border, it came under the influence of the Reformation from Switzerland. Hubmaier started socializing with the humanist Desiderius Erasmus of Rotterdam, and Johannes Oecolampadius, a reformer from Basel. Upon coming in contact with some of Luther's letters, Hubmaier began understanding the significance of the Reformational slogan, "Sola Scriptura." In his sermons, he began pointing to the importance of the Holy Scriptures and started basing his theology on it. He further affirmed his attitude through a conversation with Erasmus who had a different foundation for his approach as a humanist in $1522 .{ }^{1}$

It was exactly this Scriptural foundation which determined and formed Hubmaier as a reformer. He did not adhere to Luther nor Zwingli, but instead paved the way for a religious practice that was exclusively based on the authority of the Holy Scriptures, and without the influence of church tradition. Thus, Hubmaier's theology was independent of that of the other theologians (MacGregor 2006, 105).

In early 1520's, the Reformation spread into many parts of Europe, including the area of southern Austria, where Hubmaier was active. As a theologian with the necessary knowledge and his own attitude, he was in the right place at the right time. His debates have always been based in the Scriptures. Their theological independence often led to conflicts with other Reformers. Since the distance between the cities of Waldshut and Zürich was only $50 \mathrm{~km}$, the two Reformers, Balthasar Hubmaier and Ulrich Zwingli, began having intensive conversations. In 1523, both Hubmaier and Zwingli began a debate regarding the ending of the infant baptism practice. Sebastian Ruckensperger reported that Hubmör, (ie., Hubmaier) met with Zwingli in Zürich, who conceded to his opinion at that time that it is only right to baptize children after they have been introduced into the faith (MacGregor 2006, 107). During that time, Zwingli agreed with Hubmaier that baptizing infants was non-Biblical. Kirk MacGregor (2006, 106-108) claims that Hubmaier stopped baptizing infants sometime between 1521 and January 1523. Hubmaier was not just a theologian, but also a parishioner who took care of his

1 For the relationship between Hubmaier and Erasmus, see: Williamson, T. Daren. 2005. Erasmus of Rotterdam's Influence upon Anabaptism: The Case of Balthasar Hubmaier. Doctoral thesis. Simon Fraser University. 256 pages. 
parishioner's pastoral needs. If the parents insisted that their infants be baptized, he would baptize them, although he would personally disagree with it. This was the case with mortally ill children as well. In a letter to his friend, Hubmaier writes that, "if there are some parents of an ill child who have a great desire for their child to be baptized, I'll baptize the child" (Pipkin and Yoder 1989, 72). Balthasar Hubmaier was one of the first theologians who started practicing baptism based on belief during the Reformation. He considered his teaching to be correct, based on the examples of baptism in the Scriptures. Hubmaier said, "Judge in your mind and according to your conscience based on the true simple Word of God. However, may the Word of God itself be your peacemaker and your judge. Thus, you will not commit error." (Pipkin and Yoder 1989, 99).

After meeting with Zwingli in Zürich, Hubmaier went back to his city of Waldshut. Debates about church reforms ensued. The Waldshut church was not under the jurisdiction of the city council, unlike in Zürich. Hubmaier personally led the church changes as one "who preaches the Word of God and can therefore be in charge" (Pipkin and Yoder 1989, 31). He never used his authority to become the supreme judge in the city. He never enforced his decisions authoritatively; instead he organized debates where every citizen was allowed to participate. In this way, the citizens were able to correct Hubmaier in his attitudes.

Throughout history Hubmaier's status was twofold. Some counted him among the Anabaptists; others didn't. What's surprising is the fact that Hubmaier was only included among the Anabaptist founders after 1944, when Harold S. Bender's book, The Anabaptist Vision, was published. In note number 54, Bender concludes that Hubmaier presents only a "passing departure from the original to the authentic Anabaptism" (Bender 1944, n54).

Normative, or Evangelical, Anabaptism ${ }^{2}$ was proposed by Conrad Grebel, Felix Mantz, and early followers of Zwingli, who went on to become the members of the Swiss Brethren (Chatfield 2013, 26). They were pacifists. John Howard Yoder toned down Bender's completely negative assessment of Hubmaier. He claimed that Hubmaier "never played an important role" in the beginnings of Swiss Anabaptism, because Hubmaier had no connections to Grebel prior to the year 1523 (Yoder 1959, 5). Yoder claimed that Hubmaier's debate around baptizing infants "was not a sign of a direct contact between him and the Zürich radicals" (Yoder 1959, 6-7). In his master's thesis, Rudolph Henry Wiens notes that:

"The image of Balthasar Hubmaier, the Bavarian Anabaptist leader who lived between around 1480 and 1528 , which is what we learned during the recent researches of the beginnings of Anabaptism, is such that he would resort to vi-

2 For more about Anabaptism see: Gonzales Lucic, Antonia. 2011. Balthasar Hubmaier and early Christian tradition. Proquest, Umi Dissertation Publishing. 
olence in order to defend his stances, similarly to the Swiss reformer Zwingli, and unlike the Swiss Brethren, who went on to become the first Anabaptists. This kind of image has been around for a long time, but it was also supported in newer times by scholars such as Horsch, Bender, Bergsten, and Stayer (...) Whether this attitude is correct or not, it has resulted in a widespread disregard of some of the best early Anabaptist works, such as his "The Sum of the Entire Christian Life", which deserves to be recognized as an all-time classic" (Wiens 2010, 1).

Arnold Snyder, one of the leading historians and researchers of Anabaptism, notes that "in spite of the fact that Conrad Grebel, Felix Mantz, and Georg Blaurock were the first leaders, none of them wrote nor published any significant works in defense of adult baptism. This task befell Balthasar Hubmaier, one of the early Anabaptist leaders of great importance" (Snyder 2009,80). In note number 13 Snyder adds that,

"Hubmaier was unjustly marginalized in Mennonite writings, primarily due to the fact that he was not a pacifist. It's unusual that polygenesis historians, who usually focus on "the sword" as their central topic, are also able to marginalize Hubmaier as a "non-typical" Anabaptist. In fact, Hubmaier probably contributed to defining the early theological core of the Anabaptist teaching more than anybody. The Swiss Brethren literally quoted his writings about baptism as early as $17^{\text {th }}$ century" (Snyder 2009, 90).

While studying Hubmaier's life, his work, and his writings, I am taking into account the opinion of the historian Snyder. This is why I will be leaning towards his interpretation of this great reformer and the founder of the early Anabaptist movement.

For Hubmaier, the Bible was a foundation on which he built his interpretation of baptizing believers, and against infant baptism. The practice of paedobaptism reaches back into the $3^{\text {rd }}$ century, into early church history, and was caused by the parent's concern for the child's salvation (McGreath 2001, 528). Hubmaier argued that the act of baptism needs to follow faith as the result of Biblical teaching. Without faith, baptism is meaningless. This is why Hubmaier referred to the Scripture in Mk 16:15-16, where Jesus commands His disciples, "And He said to them, 'Go into all the world and preach the gospel to all creation. He who has believed and has been baptized shall be saved; but he who has disbelieved shall be condemned"' According to this passage, Hubmaier emphasizes the importance of three of Christ's commandments: preaching, believing, and baptism. From this, it follows that listening to the Word of God and accepting it by faith needs to precede baptism (Pipkin and Yoder 1989, 115).

Baptism is also an act of initiation into the body of Christ - His Church - as a visible ecclesial element of Christ's presence in the world. Hubmaier writes, 
"There must be an outward confession, or testimony, through which brothers and sisters get to know each other, because faith only exists in the heart" (Pipkin and Yoder 1989, 127). Aside from being a testimony, baptism is also a commitment, as it motivates the believer to act responsibly both in church and in society. Apart from symbolizing the transit from death into new life with Christ, baptism is also an act of acceptance into a local believer congregation. Hubmaier wrote, "But when the one being baptized receives the waters of baptism, he is giving a public testimony about how he has obligated himself to live in accordance with the commandments of Christ. Thanks to this pledge, he has given himself over to his sisters, brothers, and the church, so that in case of any transgression they have the authority to admonish him, punish him, forbid things, and to accept back again." (Pipkin and Yoder 1989, 127). It is important to note that Hubmaier emphasized salvation through faith alone, and not through baptism. Since the commandment of baptism was given by Christ Himself, it stops being an option and becomes an obligation. Hubmaier said that, "he who has believed should be baptized and refrain from arguing any further, because where there is water and a person to baptize them, it is their turn as far as Christ is concerned. However, if the water or a person are not available, their faith is then sufficient" (Pipkin and Yoder 1989, 124). With the robber on the cross, baptism was not possible, and yet Christ told him that he will be with Him in Paradise. That's why Hubmaier notes that all those who have a chance to be baptized should be baptized and avoid the condemnation and punishment due to Christ's words" (Pipkin and Yoder 1989, 140).

At the end of 1523, the Waldshut priest's theology was met with opposition from the Roman Catholic representatives of the city of Ensisheim in Austria. Upon his arrival in Waldshut, three accusations have been made against Hubmaier, in which he was accused of having joined "Luther's new religion," of having represented several cities during another debate with Zwingli in Zürich, and of having misinterpreted the Scriptures in his sermons. The delegation of city of Ensisheim wanted to arrest the priest and hand him over to the Bishop of Constance. However, the city council refused to extradite Hubmaier, and they defended him fervently. Finally, the delegation provided a forty-day deadline for their demands to be met. As quickly as one week later, the Waldshut city council wrote a reply to the official delegation, stating that Hubmaier was innocent. This was a call to action for the Austrian royal army. As early as in the winter of the same year, they were supposed to come to Waldshut and apprehend Hubmaier. However, because of the war in France, the army was unable to respond immediately. Such latent danger did not stop Hubmaier from being active in his pastoral work. On January $11^{\text {th }} 1524$, he sends a "Call to Brothers" to gather in his home and bring their Bibles so they could study God's word. In their meetings, they discussed religious issues and they developed their fellowship by being encouraged from the 
Scriptures (Broadbent 1989, 156). This was a preparation for the later discussions about the eighteen theses, which were going to be printed in the following three months.

In June 1524, the Austrian army called its troops from Innsbruck to attack the city of Waldshut. This activity was supported by Ferdinand the First himself, the King of the Holy Roman Empire. Due to good organization and a prepared defense made of the villagers and the citizens of Waldshut and its surrounding area, the attack was postponed. In order to prevent bloodshed, Hubmaier left Waldshut and took refuge in the Swiss city of Schaffhausen. While there, he continued to write his works. He had spent his time in the city of Schaffhausen while he was a student as well. By the end of 1524, he finished writing three works: "Eine ernstliche christliche Erbietung" (A Serious Christian Appeal), "Axiomata Schlussreden gegen Eck" (Axiomata- The Theses Against Eck), and "Von Ketzern und ihren Verbrennern" (Heretics and Those Who Burn Them). It was his desire to open up a debate about unresolved issues, and he was willing to accept differing opinions. This was not a hallmark of religious leaders of the day. He dedicated his important 36-article work, "Von Ketzern und ihren Verbrennern," to Anthony, a vicar in Constance, stating that the truth is invisible, and that the heretics are in fact all those who oppose the Scriptures. He warns Anthony that he should steer clear from his heresy and stop siding with the Pope. It is important to note that it had been 109 years since the martyr, Jan Hus, had been burned at the Council in the same town. He was a great fighter for the truth, until his very death. That is why Hubmaier's words served as a reminder, as well as a warning, considering the current events of the day. Although he claimed that there are heretics, he maintained that they should be gently pointed to the right path. Hubmaier thought that, in light of God's Word in Matthew 13, the wheat should grow together with the tares. Burning the tares is not following Christ's example, which means that those who burned others became heretics themselves, as they wanted to separate the wheat from the tares ahead of time, which was not their mission. Christians are called to fight the heathens with the sword, however this sword is not a weapon made of metal, but the Word of God. Secular authorities are called to punish evil people for worldly transgressions, but not heretics and those who believe falsely. Hubmaier believed that God will judge the heretics.

After the situation in Waldshut calmed down, Hubmaier went on a trip. In the autumn of 1524, as he was returning home from Schaffhausen to Waldshut, he stopped by in Zürich to visit Zwingli. The citizens prepared a huge welcome for him, and they started throwing away their religious images and statues. Encouraged by this act, Hubmaier resumed his fearless preaching in Waldshut.

Since he disagreed with the Church's stance on celibacy, on January $13^{\text {th }} 1525$ Hubmaier married Elizabeth Hugline, which was supported by the entire town, 
and for this act he referred to his first work. Elizabeth was devoted to her husband Baltahasar and the reform he had started. She followed and supported him faithfully. When the persecutions came, she fled together with him. She followed him faithfully until death.

Three months after their wedding, and important event happened in the life of the reformer. April 1525 marked Hubmeier's official joining the Anabaptist tradition. Wilhelm Reublin, an Anabaptist preacher who had been banished from Zürich because of preaching against the episcopal order of the city, arrived at Waldshut. He supported baptizing people based on their faith, so on April $14^{\text {th }} 1525$ he baptized Hubmaier and the other members of the clergy, around sixty of them. After this, 300 believers were baptized by Hubmaier (Broadbent 1989, 158).

In the same year, he published two more very important Anabaptist works, among others: "Eine Summe eines ganzen christlichen Lebens" (Sum of the Entire Christian Life), and "Von der christlichen Taufe der Gläubigen" (The Christian Baptism of Believers). The first work, finished in July 1525, was dedicated to the three cities in which Hubmaier had lived, and which were plagued with bad Christian practice. Those were Friedberg, Ingolstadt, and Regensburg. In the work, he uses five points to summarize the entirety of the Christian life. The second work speaks about baptism. This is probably Hubmaier's most frequently studied work. It is a reflection on Zwingli's stance on baptism, repeated baptism, and infant baptism from May 1525. This comprehensive work is divided into seven chapters. This work caused some heated arguments with Zwingli and Calvin. Hubmaier demonstrated that there are no infant baptisms in the New Testament, and that only the believers were baptized. He outlines the analogy that God's Word needs to be preached first, after which comes obedience. The analogy is accepted and results in the change of the hearts of believers. Finally, there comes repentance for sins, which results in faith. Baptism comes as the result of visible faith. In the same year, Zwingli wrote his own discussion as a response to Hubmaier's reflection.

As the Austrian army was approaching the city of Waldshut, on December $5^{\text {th }} 1525$ he and his wife fled to the nearby Zürich. Upon finding out Hubmaier was in the city, Zwingli had him arrested. A session was convened in order to investigate Hubmaier's beliefs. He was supposed to publicly denounce his attitudes. However, instead of disputing them publicly in the Fraumunster church, he defended them resolutely. He was particularly adamant about defending his stance on baptism. He was arrested immediately and tortured for seven months.

After being released from Zürich, Hubmaier went to the city of Nikolsburg in June or July 1526 (Graffagnino 2017, 13). This city was religiously tolerant and allowed reformers to work. The Anabaptist Reformation grew quickly in Nikolsburg. It is estimated that Hubmaier baptized at least six thousand people during 
his short time in the city (Estep 1986, 59), while some authors claim the number is twice as big (Nordenhaugh 1969, 66).

Nikolsburg was under the rule of the Baron Leonard Von Liechtenstein. He called the printer Simprecht Sorg from Zürich. It was his task to establish a printing shop in Nikolsburg and to keep printing Hubmaier's works. Die zwölf Artikel des christlichen Glaubens (Twelve Articles of Christian Faith) and Ein kurzes Vaterunser (A Brief Lord's Prayer) were the first works printed in Nikolsburg based on Hubmaier's manuscripts from the Zürich prison. In the Twelve Articles of Christian Faith, he defined the fundamentals of Christian belief based on the Apostolic creed. In A Brief Lord's Prayer, there are reflections about the Lord's Prayer from the Gospel of Matthew. In the book, Der uralten und gar neuen Lehrer Urteil (An Old And New Assessment of Teachers), there is an assessment of the old and the new teachers, and the stances that the church fathers such as Origen, Autanasius, Tertulian, and Hieronima had about infant baptism are outlined (Estep 1986, 56). Hubmaier contrasts their stances with those of his contemporaries, such as the German reformers Martin Luther, Johannes Oecolampadius, and Wolfgang Capito, as well as the Swiss reformers Ulrich Zwingli and Leo Jud.

Considering the fact that Baron Leonard von Liechtenstein recognized Hubmaier's creative talent and that he provided him with the necessary technical and financial support, Hubmaier was able to devote his time to writing. During the next two years (ie., between 1526 and 1528) 17 of his works were printed.

Hubmaier's works ${ }^{3}$ became characteristic due to the fact that they were all based on the Bible. It is important to view them as a collection of works about the great Reformation topics, such as baptism, church, free will, the Lord's Supper, blasphemy, and the relationship with the state. The full list can provide us with an insight into the fervor for the written word that is this reformer's legacy. This is why I am bringing you a list of his works in the original German, along with the year of publication.

1. Achtzehn Schlussreden (1524)

2. Eine ernstliche christliche Erbietung (1524)

3. Axiomata - Schlussreden gegen Eck (1524)

4. Von Ketzern und ihren Verbrennern (1524)

5. Etliche Schlussreden vom Unterricht der Messe (1525)

6. Öffentliche Erbietung (1525)

7. Eine Summe eines ganzen christlichen Lebens (1525)

8. Von der christlichen Taufe der Gläubigen (1525)

3 The full list of Hubmaier's works was provided by Westin, Gunnar and Bergsten, Torsten in their work: Quellen zur Geschichte der Täufer IX, Hubmaier, Balthasar: Schriften, Quellen und Forschungen zur Reformationsgeschichte, Gütersloh, 1962. 
9. Ein Gespräch auf Zwinglis Taufbüchlein (1525-1526)

10. Die zwölf Artikel des christlichen Glaubens (1526-1527)

11. Ein kurzes Vaterunser (1526)

12. Der uralten und gar neuen Lehrer Urteil (1525-1526)

13. Von der Kindertaufe (1526-1526)

14. Eine kurze Entschuldigung (1526)

15. Ein einfältiger Unterricht (1526)

16. Eine christliche Lehrtafel (1526-1527)

17. Grund und Ursache (1526-1527)

18. Von der brüderlichen Strafe (1526-1527)

19. Eine Form zu taufen (1526 - 1527)

20. Eine Form des Nachtmahls Christi (1526-1527)

21. Von dem christlichen Bann (1526-1527)

22. Von der Freiheit des Willens (1527)

23. Das andere Büchlein von der Freiwilligkeit des Menschen (1527)

24. Von dem Schwert (1527)

25. Eine Rechenschaft des Glaubens (1528)

Hubmaier's writings and books were spreading all across Europe. A fierce persecutor of Hubmaier's, the ruler of the Holy Roman Empire, Ferdinand I, was crowned as King of Bohemia and Hungary in 1526, and the very next year, in 1527, he became King of Croatia. Since he was a fierce persecutor of Anabaptists in his domain, he managed to stop a more intensive spread of the radical Reformation movements. Maybe that is the reason why the influence of the Anabaptist movements was very limited in Croatia. As a diagnosis of the state of affairs at the time, we have Stanko Jambrek's report,

"The early Anabaptist leaders were persecuted by everyone: the authorities, Roman Catholics, Lutherans, and Calvinists. Most of them, especially in Austria and its colonies, managed to live only a few more years after coming to God, and that on the run. Due to the ruthless persecutions, strong anti-reformational measures, and the constant struggle against the Ottoman Empire, the Anabaptist Reformation tradition never spread nor was it established in the historical Croatian lands." (Jambrek 2011, 342).

King Ferdinand I forced Baron Leonard Von Liechtenstein to respect the decision of Karl V. Habsburg from May $26^{\text {th }} 1521$ under the name of The Worms Edict, as the punishment of all "new faith believers." On August $28^{\text {th }} 1527$, Liechtenstein extradited Baltazar Hubmaier and his wife for the hearing that was held in Vienna. After the hearing, they were held captive in Castle Kreuzenstein near Vienna.

While there, Hubmaier wrote his last work, Eine Rechenschaft des Glaubens (An Account Of My Belief) for King Ferdinand I, hoping that the King would read it and spare his life. However, the King failed to react (Estep 1986, 62). 
Seven months later, on March $3^{\text {rd }}$, he was summoned to Vienna again. Seven days of torture ensued. The goal was to break Hubmaier and force him to denounce his beliefs. However, he never wavered and remained steadfast. On March $10^{\text {th }}$ the executioners took him and his wife to the stake. Hubmaier's wife kept encouraging him and exhorting him to remain faithful. He asked the brothers to pray for him so that he would be patient in his suffering. When they got to the stake, they took off his clothes and started the fire. His last words were, "O Lord, they took of Your robe off, too. I am happy to leave my clothes behind. Keep my spirit and my soul, please! (...) Dear brethren, I pray to God that He would forgive me for my guilt in this death. I wish to die in the Christian faith." As his beard and hair were catching fire, he shouted, "O Jesus, Jesus!" and he died suffocating on the smoke (Estep 1986, 63). His ashes were thrown into the Danube so that his followers could not visit his grave.

Three days later, Hubmaier's wife Elizabeth had a stone tied around her neck and was thrown into the Danube, where she drowned. This was the usual punishment that was inflicted on Anabaptists, ie., "newly baptized," by Catholics and Protestants alike. They mockingly called this act of murder as "the third baptism."

\section{Hubmaier's Eighteen Articles}

In April 1524, Hubmaier organized a debate in Waldshut, at which time he introduced his first work called, "Achtzehn schluß rede so betreffende ein gantz Cristlich leben, waran es gelegen ist" (Eighteen Articles About the Entire Christian Life, And What They Consist Of). ${ }^{4}$ It consists of eighteen articles which deal with the entirety of Christian life. The articles outline Hubmaier's theology, and the basics of his ecclesiology and pastoral practice for the believers in the Waldshut church. The booklet was published by Ramminger in 1524, and it is being kept in the Sttats und Stadtbibliothek library in Augsburg. It is eight pages long. Its contents were the basis for the ensuing debates that were aimed at church reform. Similar debates were taking place all over centers of Reformation. In Zürich, such debates were started by the city council's authority as the executive body for legal issues, discussions, and resolution implementation. In Waldshut, the debates were part of regular worship services led by Hubmaier, who held that only the one who preaches the Word of God has the right to command (Pipkin and Yoder 1989, 31). He believed that the city authorities had no right to participate in these debates

4 Transcript of the original: Glaubensstimme-Das evangelische Arhiv im Internet, Schlussreden, http://glaubensstimme.de/doku.php?id=autoren:h:hubmaier:schlussreden. (accessed on February 15th 2018). 


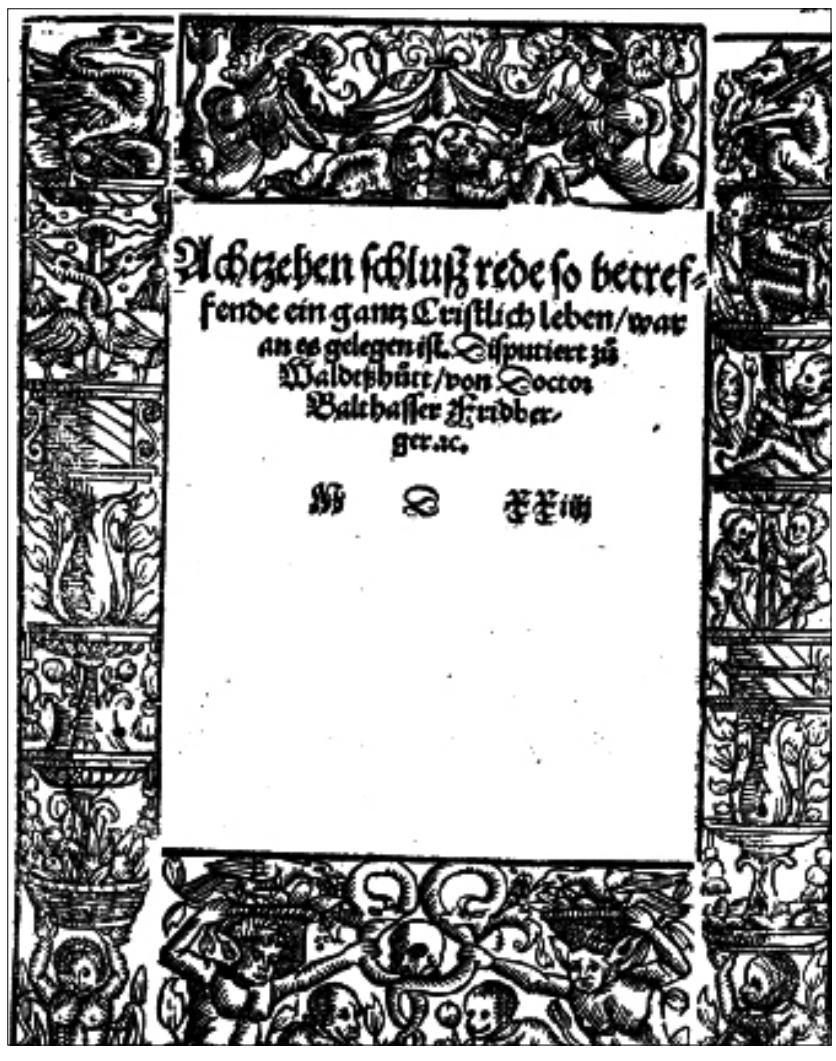

Achtzehn schluß rede so betreffende ein gantz Cristlich leben, waran es gelegen ist (Staats- und Stadtbibliothek Augsburg). Source: https:// books.google.hr/intl/hr/googlebooks/tos.html

nor in applying resolutions reached in the church. The Eighteen Articles were a sort of an introduction into the Anabaptist theological debates that Hubmaier will be talking about in his other works in the next three years. The foundation of his entire theology, as well as this booklet, rested on "the written Word of God," to which he called his believers.

ARTICLES (Vedder 1905, 69-71):

1. Faith alone justifies us before God.

2. Faith is the understanding of God's grace, which is manifested to us through the giving of His only begotten Son. This excludes all of the shame of so-called Christians, who only have a "historic belief" in God.

3. Faith cannot stay dead but must be manifested inside itself out of gratitude to God, and in works of brotherly love towards our neighbor. This precludes all ceremonies, the penance, lighting candles, or using ointment and holy water. 
Achtzehn schluß rede so betreffende ein gantz Cristlich leben, waran es gelegen ist

\section{i Derainigglaut madet ghtofrofit bot Bot.}

a Difee glannob iff bie entanotnins der batinberntgtayt

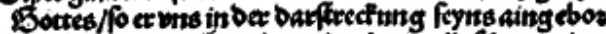

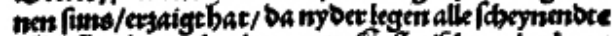

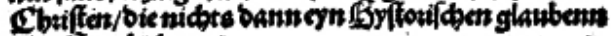
von 20tchaben.

3 Eollider glawb magntit my difig geen/ fonmoet mil ausbuedengegen Sott/ in band a agung / vnio gegen: ben men f

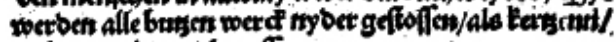
patunes vito weydwaffer.

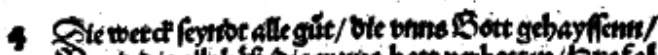

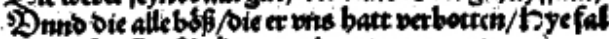

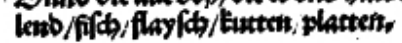

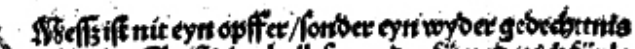

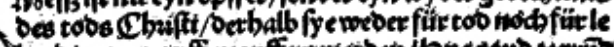

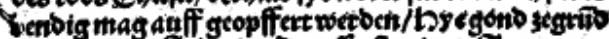

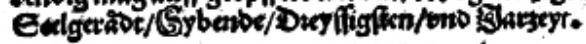

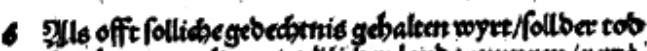

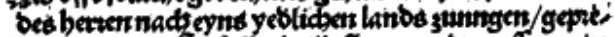

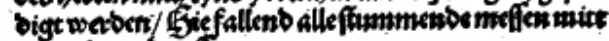

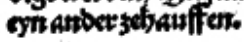

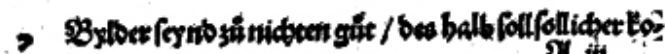

4. Only the works commanded by God are good, and only those He has forbidden are evil. This excludes the fish, the meat, the tonsure, the hood, and the platter.

5. Mass is not a sacrifice, but a remembrance of our Lord's death. It is, therefore, not a sacrifice for the dead nor the living. Thus, the souls of those who judge and lie must perish.

6. When the ceremony is celebrated, the Lord's death should be preached in the believers' mother tongue. This precludes all the Low Masses.

7. Images and statues are not good for anything. That is why no such expense should be wasted on wooden or stone images anymore, but it should rather be given as gift to the living images of God who are in need.

8. Every Christian needs to believe and be baptized personally, and it is their privilege to judge, based on the Scripture, whether their priest gave them the bread and the wine in an appropriate manner.

9. Just like Christ alone died for our sins, and just as we have been baptized 
in His name, we can have no advocate nor an intercessor before Him. This precludes all pilgrimages.

10. It is better to explain a single verse from a Psalm in the vernacular of the people, but to sing five whole Psalms in a foreign language that the people do not understand. This precludes all midnight masses, morning masses, services at $3 \mathrm{pm}$, services at 9am, the noon service, the midnight service, and night prayers.

11. All doctrines that are not based on God Himself are useless, forbidden, and should be uprooted. This is where we put in their place Aristotle, scholars like Thomas, Scott, Bonaventura, and Occam, and all the other teachers who have not been rooted in God.

12. The time is coming and it is already here, when nobody will be justified through their preacher, but through the preaching of the Word of God. This precludes all talk about morning masses, the penance, mass for the dead, and memorial masses.

13. It is it the duty of church members that, when the pure Word of God is preached to them, they should provide the food and clothing for the ministers. This precludes the jurors, the pensioners, the mediators, the absentees, the liars, and dream dabblers.

14. Those who seek purgatory believe in those whose good is their belly and who seek the tomb of Moses that they will never find.

15. Forbidding priests to marry and to mock them for their wantonness and misery is like freeing Barabbas and murdering Christ.

16. Keeping the promise of purity in human strength is nothing more than flying across the sea without any wings.

17. Those who encourage silence or who neglect the Word of God for worldly gain, they sell God's grace just as ruddy Esau sold his birthright, and all such people will be rejected by Christ.

18. Whoever does not earn his bread in the sweat of his brow is already under condemnation and not worthy of the food he is eating. All other possible condemnations are given here.

At the beginning of his booklet, Hubmaier addresses his readers with these words, "I, Balthasar, the doctor of Friedberg and pastor in Waldshut, wish grace and peace in Christ Jesus our Lord to all priest brethren, as well as the chaplain" (Estep 1986, 225).

In the introductory greeting Hubmaier introduces himself as Balthazar of Friedberg, because at the time he was probably more known for his place of birth than by his last name. In his later works, he introduced himself as Balthasar Hubmör from Friedberg. After the introduction came the foreword, 
"Beloved men and brothers, it has been an ancient custom ever since the days of the apostles that, when evil forces strike against belief, all people who wish to speak the Word of God and who think in the Christian manner need to gather in studying the Scriptures. This is done so that care for the Christian flock would, in accordance with God's Word, be taken with utmost diligence. Such a gathering is called a synod, a congregation, or a brotherhood. Such congregations are, especially in such dangerous times, able to provide our believers with honor and good will aplenty. We should not only nourish our bodies with food and drink, but we should also nurture our souls, so we can be more useful to our flock and to be able to feed it with God's Word in peace and unity. For this purpose, we need to get rid of all insulting and quarrelsome words. Therefore I advise you, men and brothers, for the sake of fellowship in brotherly love, for the sake of sacredness of Christian peace and the name of our Lord Jesus Christ, through these dissertations which I have written in the form of questions and inquiry, to adopt a Biblical foundation, so that in the next meeting of the congregation, which will be held in Waldshut, we would be able to talk to one another peacefully and as brothers. Now, in order not to waste any time with human futility and not to hurt our good reputation, bring your Bibles or, if you don't have them, then bring your missals so we could share these God-given words of the Christian message with one another. As for me, I'll do everything in my power so that you would not leave this meeting without being fed with spiritual food and without being satisfied with the spiritual drink. I greet you in the name of Jesus Christ our Saviour" (Estep 1986, 225).

This foreword was also an announcement for a debate which followed in Waldshut. It was the basis for the reform of the church and the entire city of Waldshut. After the foreword he lists the eighteen articles.

In his study of the Reformation hermeneutics, "Balthasar Hubmaier and the clarity of Scripture," Graeme Chatfield $(1993,57)$ notices that in the articles Hubmaier does not refer to the Scripture directly. This fact is indicative since the Scriptures were the foundation of Hubmaier's belief. However, even though the Scriptures are not quoted, there are direct references to four NT and ten OT passages in the Eighteen Articles.

The fact that faith is the foundation of the believer's relationship with God is touched upon in Hubmaier's first three articles. We are justified before God only by faith, based on God's grace which was given to us as gift through Christ. It is a call to reject the tradition and the "faith of the fathers," and to accept a life-giving faith which makes a change in the life of believers. Such faith cannot remain alone but is manifested in gratefulness to God and in love towards your neighbor. More about Hubmaier's stance and his doctrine regarding justification by faith can be found in Michael Whitlock's work $(2014,147)$ entitled, “Balthasar Hubmaier's Doctrine of Justification." The articles show a drift from the usual church practice 
and tradition. So for Hubmaier, things like images, statues, and holy water have no useful purpose in church.

Article 4 talks about the character of works. Only the works which have been commanded by God are good. On the other hand, only those which He forbade are bad. This leads to the loss of significant church elements, such as fish meals, meat meals, hoods, tonsures, and the platter, because those things were not commanded. Hubmaier identifies passages from Mt. 15:13; Mt 19:17, and Deut. 12:32 as saying that only the things which were commanded by God are good. In principle, commandments lead towards good, and bans prevent evil. Understanding Hubmaier's anthropology is key to understanding his soteriology (Eaton 2010, 68). Salvation is founded on the Word. The Bible does not mention a strict weekly meal of fish and non-fat foods. Also, the tonsure was a characteristic way of cutting the hair of new priests as a sign that they were about to enter the clergy. The hooded robe was the common clothes of the priests, but the Bible does not talk about it. The word, Blatten, may be translated as "leaves," or "plate." It is probably some sort of sacramental object that is part of the Mass, like a collar or a stole which was part of the priestly robes.

Article 5 provides us with Hubmaier's view on the Lord's Supper. For him, it does not represent a sacrifice, but rather a memory of Christ's sacrifice and death. The stance regarding baptism was an important determinant in the Swiss Brethren movement. This could be seen in debates with Zwingli. Hubmaier's primary source for writing his articles was the written Word of God, and as such, it was the source of all questions and revelations of God's will. For Zwingli, the written Word was an interpretation of the ordinances of the Holy Spirit through which the believer experiences the Gospel internally, and in this way discovers the will of God (Chatfield 1993, 56).

Article 6 talks about liturgical worship. When celebrating the church ceremony, the Lord's death should be preached in the believer's mother tongue. This makes the Low Mass (lat. Missa Lecta) redundant, ie., obsolete. Introducing the people's tongue into the liturgy was the hallmark of all reformers. This strengthened national identity and the development of the believer's literacy in general.

Article 7 talks about the internal structure of church buildings. By rejecting the miraculous nature of images and statues, Hubmaier sees them only as an expense. And not only in terms of setting them up, but their maintenance as well. On the other hand, those assets could have been used better for taking care and helping the needy, which would go to show Christ's love in action.

In Article 8, Hubmaier states that every Christian should have a personal faith and be baptized for themselves. Nobody can do that on anyone else's behalf. The believer has the privilege to judge. In some way, we can already see in this article what was Hubmaier's stance on baptism and authority. He makes it clear 
that faith precedes baptism, and that the absolute authority for the Christian life is the Word of God. Based on the Word, each believer has the privilege to judge whether the spiritual food that they receive in the church from their pastor is good or not. Thus, the authority of the priests has been subjected to the authority of the Holy Scriptures, and each believer in the congregation is called to judge the priest's message in light of God's Word.

Article 9 talks about intercession. Christ alone died for the sins of all mankind. He did not do it in cooperation with saints or patrons which believers asked for Christ's help. Just as Christ alone died for our sins, every believer needs to be baptized in His name, and this does not require any intercessors. Hubmaier emphasizes that this makes all pilgrimages obsolete.

In Article 10, Hubmaier emphasizes the importance of Scriptures in the people's tongue. The people need to understand what they are being told, and he claims that it is better to explain a single Psalm verse in the tongue of the people, than to sing five entire Psalms in a language that people do not understand. Considering the church practice of the day and the usage of Latin in liturgy, many church services lost their meaning because the believers could not understand them.

In Article 11, Hubmaier re-establishes the importance of the foundation of his belief in God. Matthew 15:13 says, "Every plant which My Heavenly Father did not plant shall be uprooted." Since this was the time of the development of the humanist teachings, which were not based on the Word of God, Hubmaier considers them to be useless, and he lists by name all the philosophers and thinkers whose beliefs he categorically rejects.

Article 12 says that Christ should be placed at the center of worship, instead of the preacher taking up the position. Justification for this is found in God's Word, and not in the preacher's intercession. Thus, the priest loses the authority as the one who makes decisions and determines penance, the fate of the soul, or that of the dead. Again, Hubmaier points to the authority of Scriptures.

In Article 13, Hubmaier uses the phrase, kirchgenossen, which refers to the parishioners, or church members. However, it does not only include formal membership, but the active participation of the believers with all the duties and responsibilities, which was immensely different from the concept of passive parishioners. The believer shared active responsibility for their brothers in Christ. It was his duty to see to it that everyone's got food to eat, clothes to wear and the protection of the people they're with. This referred especially to those who have been "exposed to the clear, pure, and immutable Word of God" (Pipkin and Yoder 1989, 33-34). For the image of dream-dabblers, he alludes to the passage in Jr 23:25-32.

In Article 14, where he talks about Purgatory, Hubmaier considers that the 
basis of this doctrine boils down to making clergy rich, and nothing more. He states that "those who seek Purgatory believe in those whose good is their belly, and who seek the grave of Moses, which they'll never find." As is known from the Old Testament, the location of Moses's grave is unknown. While writing this article, Hubmaier refers to the Scriptures in Phil. 3:19 and Deut. 34:6. Just as his grave cannot be found, neither can Purgatory, and it is only useful for amazing riches by those who should be preaching God's Word.

Article 15 talks about celibacy, but from a fresh perspective in terms of the circumstances of the day. When talking about celibacy, Hubmaier sees it as something that is impractical and unnatural. Hubmaier interprets the literary text by using word images. He compares their prohibition to get married and tolerance of the mockery in regards to their physical indiscipline, misery, and immorality, with releasing the thief and criminal Barabbas, and murdering the innocent Christ.

In Article 16, he talks about moral purity once again. Adhering to celibacy in human strength is impossible. It is like flying without wings across great sea expanses.

Article 17 encourages the believers to choose truth and justice. One cannot remain neutral. Hubmaier condemns bribed silence or suppressing the truths which have been clearly laid out in the Scriptures. Such people will be rejected by Christ, just like Esau, who was the firstborn and could have received the father's blessing but decided to sell it.

Article 18 encourages work ethics in accordance with Scriptures from Genesis. All those who want to earn their daily bread easily are not worthy of the food they are eating.

At the very end, Hubmaier finishes his articles with the familiar phrase, "Die warhet ist untödlich." This phrase can be translated in three different ways: the truth is immortal; the truth is invisible; or, the truth is indestructible. For the correct interpretation of this saying of Hubmaier's we need to take all three notions into account.

After publishing his articles, Hubmaier started applying them immediately. By the end of the year, he threw out all images and statues out of the church. In a letter to his friend, he writes that Christ has taken residence in his life for the first time (Estep 1986, 51). This change resulted in a brave testimony and a determined spread of the Gospel.

\section{Conclusion}

Balthasar Hubmaier was a leading intellectual at the beginning of the Anabaptist movement, and he gave an enormous contribution to the development of this wing of the Reformation. Anabaptists were persecuted from all sides, they from 
their Swiss center to Bohemia and the Netherlands, and later on they found safety in the New World. The spark of Anabaptism, which was started in the heart of Europe, will become reignited again in Europe and all over the world after many centuries. Today's churches of Reformation heritage were born from the foundations of early Anabaptism, and are involved in the Evangelical movement that comprises of the fastest growing Christian churches in the world.

This brief work, which comprises of just 18 articles, represents Hubmaier's zealousness in exhorting believers regarding the importance of going back to the source - ad fontes. This source is God's Word, on which Hubmaier built his entire Christian life. This Word was and remains the foundation of Church reform and the driving force of change in accordance with God's commands.

Hubmaier's famous saying went, "The truth is immortal." ${ }^{5}$ This truth is Christ Himself. Jesus is the truth, the way, and the life. Hubmaier lived for this truth, he died for it, and through it he has the immortal and eternal life with his Savior, whom he followed until the very death.

His 18 articles have been a guideline for Christians around the world for almost half a century.

\section{Bibliography}

Armour, Rollin S. 1966. Anabaptist Baptism: A Representative Study. Scottdale. Herald Press.

Bergsten, Torsen. 1978. Balthasar Hubmaier: Anabaptist Theologian and Martyr. Valley Forge. PA Judson.

Broadbent, E. H. 1989. Jedna povijest crkve. Zagreb. KC Betanija.

Bender, S. Harold. 1944. The Anabaptist Vision. Herold Press.

Chatfield, Graeme Ross. 1993. "Balthasar Hubmaier and the clarity of Scripture." Disertation. University of Bristol.

Chatfield, Graeme Ross. 2013. Balthasar Hubmaier and the Clarity of Scripture. Eugene. Pickwick Publication.

Eaton Toward, Matthew. 2010. An Anabaptist Covenantal Soteriology: A Dialogue with Balthasar Hubmaier and Contemporary Pauline Scholarship, Mennonite Quarterly Review 84, no. 1. 67-93.

Estep, W. R. 1986. Istina je neuništiva. Novi sad. Dobra vest.

Graffagnino J. Jason. 2017. Balthasar Hubmaier: The Theologian of The Ana-

5 For more on the subject see: Klager, P. Andrew. „Truth is Immortal: Balthasar Hubmaier (c.1480-1528) and the Church Fathers", doctoral dissertation, University of Glasgow, 2011. 
baptist, Nikolsburg and Catechetical Instruction: A Labor of Love. Perichoresis Volume 15. Issue 4. 13-32.

Hubmaier, Balthasar, 1524. Achtzehen schluß rede so betreffende ein gantz Cristlich leben, waran es gelegen ist. Augsburg Ramminger/Staats- und Stadtbibliothek. https://books.google.hr/books/about/Achtzehen_ schlu\%C3\%9F_rede_so_betreffende_ei.html?id=4pYFmdRCd1YC\&redir_ esc $=y$ (accessed 18.02.2018).

Jambrek, Stanko. 2011. O anabaptističkoj tradiciji reformacije i Schleitheimskom vjeroispovijedanju. Kairos: Evanđeoski teološki časopis 2/2011. 342343.

Klager, P. Andrew. 2011. “Truth is Immortal: Balthasar Hubmaier (c.1480-1528) and the Church Fathers". Disertation. University of Glasgow.

Lansen, Andreas. Schlussreden. http://glaubensstimme.de/doku.php?id=autore n:h:hubmaier:schlussreden. (accessed 15.02.2018).

MacGregor, Kirk R. 2006. The Sacramental Theology of Balthasar Hubmaier. Lanham. University Press of America.

McGreath, Alister E. 2001. Christian Theology. Maden. Blackwell.

Matošević, Lidija. 2007. Rasprava o krštenju između Luthera i Anabaptista promatrana u kontekstu srednjovjekovne teologije. Bogoslovska smotra 77, br $1,121-155$.

Nordenhaugh, J. 1969. Umro je za slobodu vjere. Glasnik baptističkih crkava u SFRJ, broj 5 (17) godina II, 65-66.

Pipkin, H. Wayne i Yoder, John. Howard. 1989. Balthasar Hubmaier, Theologian of Anabaptism. Scottdale. Herald Press.

Smithson, R. 1935. The Anabaptists: Their Contribution to our Protestant Heritage. London. James Clarce and Co.

Snyder, C. Arnold. 2009. Povijest i teologija anabaptizma. Zagreb. TFMVI.

Vedder, Henry. 1905. Balthasar Hubmeier, the leader of Anabaptists. London. Putnam's Sons.

Wiens, Rudolph Henry. 2010. “Balthasar Hubmaier’s Sword: A Circumstantial Development.” Master's thesis. University of Waterloo.

Westin, Gunnar i Torsten Bergsten. 1962. Quellen zur Geschichte der Täufer IX, Hubmaier, Balthasar: Schriften, Quellen und Forschungen zur Reformationsgeschichte. Gütersloh. Gerd Mohn.

Whitlock, Michael. 2014. Balthasar Hubmaier's Doctrine of Justification. Southwestern Journal of Theology. Volume 56. Number 2, 147.

Williamson, T. Daren. 2005. "Erasmus of Rotterdam's Influence upon Anabap- 
tism: The Case of Balthasar Hubmaier." Disertation. Simon Fraser University.

Yoder, J. H. 1959. Balthasar Hubmaier and the Beginnings of Swiss Anabaptist. $M Q R$ 33. 5- 17.

Translated from Croatian by Davor Edelinski

Danijel Časni

\title{
Balthasar Hubmaier i njegovih osamnaest teza
}

\begin{abstract}
Sažetak
U radu se govori o istaknutom anabaptističkom reformatoru Balthasaru Hubmaieru koji je svojim djelima dao značajan doprinos razvoju ranoga anabaptističkog pokreta. 2018. godine se prisjećamo 490. godišnjice njegove smrti spaljivanjem na lomači zbog vjerskih uvjerenja. U radu se predstavlja Hubmaierova biografija i daje pregled njegova stvaralaštva. Posebna pažnja posvećuje se njegovu prvom radu koji sadrži 18 teza, iz lipnja 1524., pod nazivom "Achtzehn schluß rede so betreffende ein gantz Cristlich leben". U tezama je vidljiv Hubmaierov pogled na teologiju, ekleziologiju i pastorologiju na početku njegova reformacijskog djelovanja.
\end{abstract}

